\title{
PENGEMBANGAN BAHAN AJAR FISIKA DASAR BERBASIS E-MODUL DI PENDIDIKAN TEKNIK BANGUNAN UNIVERSITAS NEGERI JAKARTA
}

\author{
M. Agphin Ramadhan 1 , Santoso Sri Handoyo 2 , dan M. Mahameru Alfarisi ${ }^{3}$ \\ ${ }^{1,2,3}$ Pendidikan Teknik Bangunan, FT, UNJ \\ Email: aghpin@unj.ac.id
}

\begin{abstract}
ABSTRAK
Penelitian ini bertujuan untuk menghasilkan bahan ajar berbasis e-modulpada matakuliah Fisika Dasardi Program Studi Pendidikan Teknik Bangunan Universitas Negeri Jakarta, untuk menunjang proses pembelajaran, baik didalamkelas maupun secara mandiri. Penelitian dilakukan pada bulan April 2020 - Agustus 2020.Penelitian menggunakan metode Research and Development (R\&D) dengan model pengembangan 4D. Model pengembangan 4D terdiri dari empat tahap: Define, Design, Development, dan Disseminate. Pengumpulandata melalui angket analis is kebutuhan, validasi bahan ajar oleh para ahli, dan menilaipengg una bahan ajar.Penelitian ini menghasilkan produk bahan ajarberupa e-modul yang terdiridari 7 (tujuh) materi. Penilaian oleh ahli media diperoleh data pada persentase validitas e-modul $90 \%$, termasuk kateg ori s angat lay ak. Penilaian oleh ahlimateri diperoleh persentase rata-rata data validitas e-modul sebes ar $82 \%$ dan termasuk dalamkategorisangatlayak.Hasil penilaian pengguna produk memperoleh nilai 4,24 dan kategori sangat baik, dan hasil pre-test dan post-test menunjukkan adanya peningkatan skor peserta sebesar $39 \%$ setelah menggunakan e-modul.
\end{abstract}

Kata kunci: Pengembangan, Bahan ajar, E-Modul, Fisika dasar

\section{ABSTRACT}

This study aims to produce e-module-based teaching materials in the Basic PhysicscourseattheJakarta State University Building Engineering Education Study Program to support the learning process, bothinthe classroom and independently. Research in April 2020 - August 2020. This research uses the Research and Development $(R \& D)$ method with a $4 D$ development model. The $4 D$ development model consists offourstages: Define, Design, Development, and Disseminate. They collect data through aneedsanalysisquestionnaire, validate teaching materials by experts, and assess teaching material users. This research resulted inateachingmaterial product in an e-module consisting of 7 ( seven) materials. Assessment by media experts obtained data on the percentage ofe-module validity, $90 \%$, and a very feasible category. Assessment by materialexpertsobtainedthe average percentage ofe-module validity data, $82 \%$, and it falls into a very feasible category. The productuser assessment results obtained a value of 4.24 and very good category, and the results of the pre-testandpost-test showed an increase in the participant's score by $39 \%$ after using the e-module.

Keywords: Development, Teaching materials, E-Module, Basic physics

\section{PENDAHULUAN}

Penerapan ilmu fisika dapat dilakukan di berbagai bidang, salah satunya dalam bidang teknik sipil. Pada bidang teknik sipil, ilmu fisika merupakan salah satu pondasi dalam mempelajari sifat dari berbagai bangunan struktur yang direncanakan sehingga materi yang disajikan merupakan dasar dalam mempelajari berbagai perkuliahan pada bidang teknik sipil. Pada umumnya perkuliahan pada Program Studi
Pendidikan Teknik Bangunan (PTB) UNJ menggunakan sistem pembelajaran di dalam kelas serta menggunakan materi pada Power Point sebagai bahan ajar. Menurut Rachmat \& Winata, (2019: 42) menjelaskan bahwa keefektifan penggunaan Power Point bergantung pada persiapan pendidik dalam menyiapkan dan menyampaikan materi. Materi pada PowerPoint umumnya dibuat untuk menampilkan poin penting, sehingga tidak memuat materi secara mendetail. Begitu pula pada mata kuliah fisika dasar, 
paparan materi oleh dosen hanya menampilkan poin-poin penting, konsepkonsep utama, dan contoh soal, tidak menjelaskan teori-teori secara mendetail. Selain itu mahasiswa tidak mencari sumber lain sebagai bahan ajar, sehingga pengembangan bahan ajar diharapkan menjadi salah satu solusi untuk masalah tersebut. Penyelenggaraan perkuliahan berprinsip pada efisiensi serta efektivitas dalam pemanfaatan waktu yang terbatas secara optimal untuk mencapai tujuan pembelajaran (Budiyanto, dkk., 2019: 83). Lembaga pendidikan perlu menyediakan, mengembangkan, dan memanfaatkan beragam media pembelajaran serta memberikan kesempatan bagi mahasiswa untuk belajar sesuai dengan kebutuhan dan gaya belajar masing-masing sehingga diharapkan proses pembelajaran menjadi lebih efisien (Widalisma \& Lestari, 2017: 42).

Pemilihan bahan ajar sebaiknya disesuaikan dengan keadaan peserta didik, kemampuan SDM yang tersedia, serta ketersediaan sarana dan prasarana pada lembaga pendidikan (Rivalina, 2017: 142). Terkait hal tersebut, saat ini tengah dikembangkan sistem e-learning berbasis Moodle yang diluncurkan pada tahun 2018 dan dapat diakses melalui situs www.s1ptbunj.com. E-learning merupakan pembelajaran yang fleksibel karena baik pendidik maupun peserta didik dapat mengakses bahan ajar tanpa ada hambatan tempat dan waktu (Khoir, dkk., 2020: 3).

Berdasarkan hasil analisis kebutuhan yang dilakukan pada mahasiswa angkatan 2018 dan 2019, Program Studi PTB FT UNJ dengan total responden 90 mahasiswa menyatakan bahwa sebanyak 90 mahasiswa (100\%) menjawab perlu dilakukan pengembangan bahan ajar pada mata kuliah fisika dasar. Kemudian sebanyak 67 mahasiswa $(74,4 \%)$ menjawab pernah menggunakan e-modul dan sebanyak 52 mahasiswa $(57,8 \%)$ menyukai e-modul untuk diterapkan pada mata kuliah fisika dasar. Maka berdasarkan hasil analisis kebutuhan dapat disimpulkan bahwa perlu dilakukannya pengembangan bahan ajar mata kuliah fisika dasar berbasis e-modul.

Pada mata kuliah fisika dasar di Program Studi PTB FT UNJ pengembangan e-modul belum dilakukan. Modul memiliki sifat self instructional sehingga dirancang untuk dapat dipelajari secara mandiri yang mencakup keseluruhan materi, metode pembelajaran, dan evaluasi serta disusun secara sistematis sehingga dapat menarik minat belajar peserta didik (Sumarna, dkk., 2019: 91). Pembelajaran dengan menggunakan e-modul memiliki tujuan agar peserta didik dapat belajar secara mandiri dan mengukur kemampuan diri melalui hasil belajar sehingga pembelajaran lebih efektif untuk mencapai tujuan pembelajaran (Kurniawan, dkk., 2018: 187).

Dalam rangka penyesuaian bahan ajar terhadap perkembangan teknologi, belum dikembangkannya e-modul pada mata kuliah fisika dasar, serta hasil analisis kebutuhan yang menyatakan bahwa perlu dilakukannya pengembangan bahan ajar, maka hal tersebut menjadi alasan dikembangkannya bahan ajar berbasis emodul untuk mata kuliah fisika dasar. Pengembangan e-modul fisika dasar ini diharapkan dapat menjadi salah satu alternatif mahasiswa untuk belajar secara mandiri tanpa khawatir keterbatasan tempat dan waktu serta memudahkan dosen dalam mengelola dan merencanakan pembelajaran menjadi lebih sistematis, memberikan tugas dan melakukan evaluasi. 


\section{METODE}

Penelitian dilaksanakan pada bulan April sampai dengan bulan Agustus 2020 di Program Studi PTB UNJ dan bertujuan untuk menghasilkan produk bahan ajar berupa e-modul fisika dasar yang terdiri dari tujuh materi, yaitu: Besaran dan Satuan, Konsep Vektor, Hukum Newton, Gaya dan Penguraiannya, Kesetimbangan Benda Tegar, Impuls, Momentum, dan Momen Inersia, serta Tegangan dan Regangan. Penelitian menggunakan metode Penelitian dan Pengembangan (R\&D) untuk mengembangkan suatu produk baru, dan model penelitian 4D (Four-D) yang terdiri dari empat tahapan utama, yaitu : (1) Define; (2) Design; (3) Development; (4) Disseminate, namun pada penelitian ini tahap disseminate dibatasi hanya sampai diseminasi terbatas. Pengumpulan data pada menggunakan non tes, yaitu penyebaran angket untuk mengetahui kelayakan dari produk e-modul mata kuliah fisika dasar yang dikembangkan, penilaian pengguna terhadap produk, serta uji efektifitas. Penilaian kelayakan e-modul dilakukan oleh ahli media dan ahli materi, serta uji efektifitas e-modul dilakukan dengan uji coba terbatas menggunakan metode pre-test dan post-test, kemudian dilanjutkan dengan penilaian pengguna terhadap produk.

\section{HASIL DAN PEMBAHASAN}

Penelitian ini menghasilkan produk emodul fisika dasar. E-Modul fisika dasar ini dibuat menggunakan bantuan perangkat lunak Adobe Photoshop CS4 untuk pembuatan sampul dan Microsoft Office Word 2013 untuk penyusunan materi. EModul fisika dasar ini dilengkapi dengan gambar ilustrasi yang mendukung materi pembahasan serta dilengkapi dengan hyperlink dengan tujuan memudahkan pembaca untuk berpindah dari satu halaman ke halaman lainnya. E-modul ini juga dilengkapi dengan $\mathrm{QR}$ code dan link yang memuat video terkait materi pembelajaran. Pada bagian akhir e-modul terdapat rangkuman dan tes formatif dengan format esai berjumlah lima soal pada setiap modulnya untuk mengetahui kemampuan peserta didik terhadap penguasaan modul tersebut. Modul yang diberikan ke peserta didik dan dosen pengampu akan sedikit berbeda. Peserta didik diberikan modul berdasarkan materi pada setiap pertemuannya, sedangkan modul untuk dosen pengampu mata kuliah fisika dasar akan diberikan e-modul fisika dasar versi lengkap yang terdapat kunci jawaban untuk setiap tes formatif. E-Modul akan diintegrasikan dengan e-learning milik PTB FT UNJ berbasis Moodle. Moodle dapat diakses secara daring sehingga dapat mengatasi terbatasnya frekuensi tatap muka antara dosen dengan mahasiswa sehingga tujuan pembelajaran dapat tercapai (Herayanti, dkk., 2017: 2015).

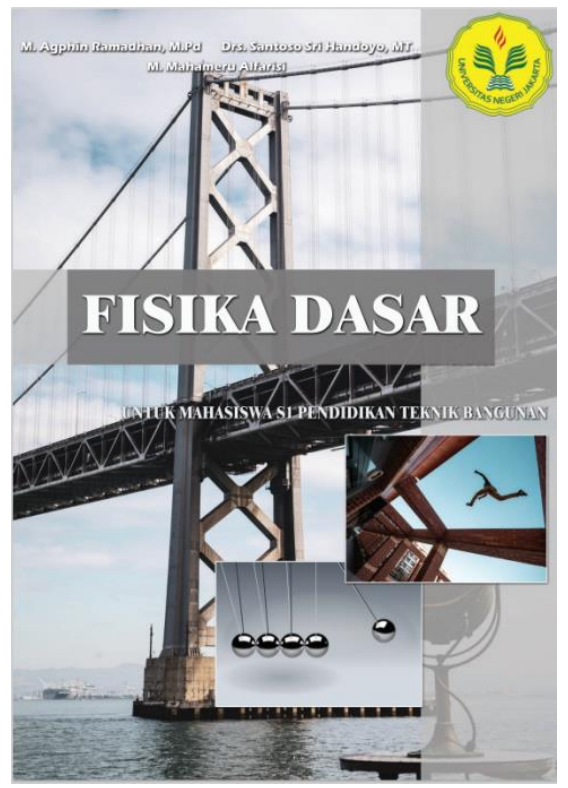

Gambar 1. Halaman Depan E-Modul 
Pengembangan Bahan Ajar ... (Agphin/ hal. 117-123)

Penilaian oleh ahli media dinilai dari beberapa aspek, yaitu aspek tampilan desain, aspek kemudahan, aspek pemanfaatan, aspek konsistensi dan format, serta aspek kegrafikan. Pada penelitian ini terdapat ahli media yang menilai kelayakan bahan ajar dari segi media. Hasil penilaian didapatkan data bahwa persentase validitas e-modul yaitu sebesar 90\%. Persentase tersebut menunjukkan bahwa e-modul masuk ke dalam kategori sangat layak untuk digunakan untuk mata kuliah fisika dasar sebagaimana dideskripsikan hasil penilaian validator pada Tabel 1.

Tabel 1. Data Validasi Ahli Media

\begin{tabular}{lcc}
\hline Aspek Penilaian & Persentase & Kategori \\
\hline Tampilan Desain & $93 \%$ & $\begin{array}{c}\text { Sangat } \\
\text { Layak }\end{array}$ \\
\hline Kemudahan & $93 \%$ & $\begin{array}{c}\text { Sangat } \\
\text { Layak }\end{array}$ \\
\hline Pemanfaatan & $88 \%$ & $\begin{array}{c}\text { Sangat } \\
\text { Layak }\end{array}$ \\
\hline $\begin{array}{l}\text { Konsistensidan } \\
\text { Format }\end{array}$ & $92 \%$ & $\begin{array}{c}\text { Sangat } \\
\text { Layak }\end{array}$ \\
\hline Kegrafikan & $80 \%$ & $\begin{array}{c}\text { Layak } \\
\text { Rata-rata }\end{array}$ \\
\hline
\end{tabular}

Berdasarkan hasil dari validasi materi oleh ahli didapatkan data bahwa e-modul mata kuliah fisika dasar yang telah dibuat memiliki total rata-rata persentase sebesar $82 \%$ yang menunjukkan bahwa e-modul yang dikembangkan masuk ke dalam kategori sangat layak dari segi materi, sebagaimana detail peniliaan validator terkait materi dapat dilihat pada Tabel 2.

Tabel 2. Data Validasi Ahli Materi

\begin{tabular}{lcccc}
\hline Modul & Persentase & $(\%)$ & \multicolumn{2}{c}{ Rata-rata } \\
P1 & V2 & Persentase & Kategori \\
\hline 1 & 81 & 82 & 81 & $\begin{array}{c}\text { Sangat } \\
\text { Layak }\end{array}$ \\
\hline 2 & 81 & 82 & 81 & Sangat
\end{tabular}

\begin{tabular}{lcccc}
\hline Modul & Persentase & (\%) & $\begin{array}{c}\text { Rata-rata } \\
\text { Persentase }\end{array}$ \\
\hline & & & & \\
\hline 3 & 81 & 84 & 82 & $\begin{array}{c}\text { Sangat } \\
\text { Layak }\end{array}$ \\
\hline 4 & 81 & 86 & 83 & $\begin{array}{c}\text { Sangat } \\
\text { Layak }\end{array}$ \\
\hline 5 & 81 & 86 & 83 & $\begin{array}{c}\text { Sangat } \\
\text { Layak }\end{array}$ \\
\hline 6 & 81 & 86 & 83 & $\begin{array}{c}\text { Sangat } \\
\text { Layak }\end{array}$ \\
\hline 7 & 81 & 83 & 82 & $\begin{array}{l}\text { Sangat } \\
\text { Layak }\end{array}$ \\
\hline $\begin{array}{l}\text { Rata- } \\
\text { rata }\end{array}$ & $\mathbf{8 1}$ & $\mathbf{8 4}$ & $\mathbf{8 2}$ & $\begin{array}{l}\text { Sangat } \\
\text { Layak }\end{array}$ \\
\hline & & & & \\
\hline
\end{tabular}

Uji efektifitas dilakukan untuk mengetahui apakah produk bahan ajar yang dikembangkan dapat memberikan pengaruh bagi mahasiswa, terutama dalam penilaian kognitif. Uji efektifitas pada penelitian ini dilakukan dengan uji coba terbatas dan penilaian pengguna terhadap produk yang dikembangkan. Uji coba terbatas dilakukan dengan metode pre-test dan post-test, dari hasil dan penilaian pengguna terhadap produk dilakukan oleh peserta uji coba terbatas setelah menggunakan e-modul yang dikembangkan. Peserta uji coba terbatas adalah mahasiswa PTB UNJ angkatan 2019 dengan jumlah 10 (sepuluh) peserta dan dilakukan menggunakan bantuan Google Classroom karena keterbatasan pandemi Covid-19. Hasil dari uji coba terbatas dapat dilihat pada Tabel 3.

Tabel 3. Hasil Uji Coba Terbatas

\begin{tabular}{lcc}
\hline \multicolumn{1}{c}{ Nama Peserta } & $\begin{array}{c}\text { Nilai } \\
\text { Pre-test }\end{array}$ & $\begin{array}{c}\text { Nilai } \\
\text { Post-test }\end{array}$ \\
\hline AJP & 75 & 90 \\
\hline AIQ & 75 & 100 \\
\hline EWP & 50 & 85 \\
\hline IB & 55 & 95 \\
\hline MF & 85 & 95 \\
\hline
\end{tabular}


Pengembangan Bahan Ajar ... (Agphin/ hal. 117-123)

\begin{tabular}{lcc}
\hline Nama Peserta & $\begin{array}{c}\text { Nilai } \\
\text { Pre-test }\end{array}$ & $\begin{array}{c}\text { Nilai } \\
\text { Post-test }\end{array}$ \\
\hline MNV & 60 & 90 \\
\hline MJA & 75 & 95 \\
\hline RH & 75 & 90 \\
\hline SNI & 25 & 70 \\
\hline SAR & 65 & 80 \\
\hline Rata-rata & 64 & $\mathbf{8 9}$ \\
\hline
\end{tabular}

Berdasarkan Tabel 3 dapat dilihat bahwa perolehan nilai rata-rata peserta uji coba terbatas di kegiatan pre-test sebesar 64 kemudian terjadi peningkatan nilai rata-rata sebesar 39\% menjadi 89 setelah mengikuti post-test. Maka dapat disimpulkan bahwa terjadi peningkatan nilai rata-rata peserta uji coba terbatas sebesar $39 \%$ setelah mempelajari e-modul mata kuliah fisika dasar yang diberikan. Kemudian penilaian pengguna terhadap produk e-modul fisika dasar yang dikembangkan dinilai dari beberapa aspek, yaitu aspek desain tampilan, aspek kemudahan pengguna, serta aspek materi dan evaluasi. Penilaian dilakukan dengan menyebar kuisioner melalui google form yang diberikan setelah peserta uji coba terbatas menyelesaikan tahap post-test. Hasil dari penilaian pengguna terhadap produk dapat dilihat pada Tabel 4 berikut.

Tabel 4. Penilaian Pengguna terhadap Produk

\begin{tabular}{ccc}
\hline AspekPenilaian & Skor & Kategori \\
\hline Tampilan Desain & 4,2 & Baik \\
\hline Kemudahan & 4,3 & Sangat Baik \\
\hline Materi dan Evaluasi & 4,23 & Sangat Baik \\
\hline Rata-rata & $\mathbf{4 , 2 4}$ & Sangat Baik \\
\hline
\end{tabular}

Berdasarkan Tabel 4 dapat dilihat bahwa perolehan rata-rata pada setiap aspek penilaian adalah 4,24 dan masuk ke dalam kategori "Sangat Baik" yang artinya mahasiswa atau pengguna puas terhadap bahan ajar yang dikembangkan. Hasil penelitian ini relevan dengan penelitian yang dilakukan oleh Sari dkk., (2019) dengan judul Pengembangan Modul Elektronik Berbasis POEI (Prediksi, Observasi, Eksperimen, Implementasi) pada Mata Kuliah Fisika Teknik" memperoleh persentase skor $80 \%$ untuk validasi materi dan termasuk dalam kategori valid, sedangkan validasi media sebesar $86,36 \%$ dan termasuk kategori sangat valid.

Adapun beberapa keterbatasan pada penelitian ini yang dapat menjadi pertimbangan untuk lebih diperhatikan lagi pada penelitian selanjutnya, yaitu : (1) Uji coba terbatas dilakukan secara online dengan menggunakan google classroom; (2) Peserta uji coba terbatas hanya berjumlah sepuluh orang dari mahasiswa PTB UNJ angkatan 2019; (3) E-Modul yang dilakukan uji efektifitas melalui uji coba terbatas hanya satu modul, yaitu modul pertama dengan judul Besaran dan Satuan.

\section{SIMPULAN}

Penelitian ini menggunakan metode Penelitian dan Pengembangan (R\&D) serta mengadaptasi model pengembangan 4D. Penelitian dan pengembangan yang dilakukan menghasilkan produk bahan ajar berupa e-modul mata kuliah fisika dasar. Bahan ajar terdiri dari 7 (tujuh) modul yang pada setiap modulnya berisikan materi untuk setiap bab dan mengacu pada Rancangan Pembelajaran Semester (RPS) mata kuliah fisika dasar. Produk bahan ajar ini diharapkan dapat memudahkan dosen dalam memberikan pembelajaran serta memudahkan mahasiswa dalam memperoleh berbagai informasi yang 
Pengembangan Bahan Ajar ... (Agphin/ hal. 117-123)

dibutuhkan terkait materi pembelajaran. Bahan ajar ini juga diharapkan mampu mendukung pembelajaran mandiri mahasiswa. Penilaian kelayakan e-modul oleh ahli media memperoleh persentase nilai sebesar $90 \%$ yang menunjukkan bahwa emodul masuk dalam kategori "Sangat Layak" dan layak digunakan sebagai bahan ajar mata kuliah fisika dasar dari segi multimedia. Selanjutnya penilaian e-modul oleh ahli materi memperoleh persentase nilai rata-rata sebesar $82 \%$ dan masuk dalam kategori "Sangat Layak" dari segi materi sehingga dapat disimpulkan bahwa e-modul mata kuliah fisika dasar yang dikembangkan sangat layak untuk digunakan pada perkuliahan fisika dasar. Bahan ajar mata kuliah fisika dasar berbasis e-modul yang dikembangkan dapat menjadi salah satu alternatif bahan ajar. Bahan ajar yang dikembangkan berbasis elektronik sehingga dapat digunakan tanpa ada hambatan tempat dan waktu serta dibuat dengan bahasa yang mudah dipahami dan didesain semenarik mungkin supaya dapat memotivasi mahasiswa dan mendukung pembelajaran secara mandiri.

\section{DAFTAR RUJUKAN}

Budiyanto, M., Sudibyo, E., \& Qosyim, A. (2019). Pembelajaran Fisika Dasar Menggunakan E-Learning Untuk Meningkatkan Literasi Sains Mahasiswa. Jurnal Penelitian Pendidikan IPA, 3(2), 82. https://doi.org/10.26740/ippipa.v3n2 .p82-86.

Herayanti, L., Fuaddunnazmi, M., \& Habibi, H. (2017). Pengembangan Media Pembelajaran Berbasis Moodle pada Mata Kuliah Fisika Dasar. Jurnal
Pendidikan Fisika Dan Teknologi, 1(3), 205. https://doi.org/10.29303/jpft.vli3.26 $\underline{0}$.

Khoir, H. M., Murtinugraha, R. E., \& Musalamah, $\mathrm{S}$. (2020). Pengembangan Media Pembelajaran E-Learning Berbasis Moodle Pada Mata Kuliah Metodologi Penelitian. JurnalPensil : Pendidikan Teknik Sipil, $\quad$ 9(1), 54-60. https://doi.org/10.1017/CBO978110 7415324.004.

Kurniawan, E. D., Nopriyanti, \& Syofii, I. (2018). Pengembangan Modul Elektronik Berbasis Pendekatan Saintifik Pada Matakuliah CAD/CAM. Jurnal Pendidikan Teknik Mesin, 5(2), 185-194.

Rachmat, L., \& Winata, H. (2019). Kompetensi profesional guru dan media pembelajaran powerpoint sebagai upaya untuk meningkatkan efektivitas pembelajaran. Jurnal Pendidikan Manajemen Perkantoran, 4(1), 38. https://doi.org/10.17509/jpm.v4i1.1 4953.

Rivalina, R. (2017). Strategi Pemanfaatan ELearning Dalam Mengatasi Keterbatasan Jumlah Dosen. Kwangsan: Jurnal Teknologi Pendidikan, 5(2), 129-145.

Sari, D. P., Syofii, I., \& Rukiyah. (2019). Pengembangan Modul Elektronik Berbasis POEI (Prediksi, Observasi, Ekperimen, Interpretasi) pada Mata Kuliah Fisika Teknik. Jurnal 
Pengembangan Bahan Ajar ... (Agphin/ hal. 117-123)

Penelitian Pendidikan, 18(3), 276283.

Sumarna, K., Maulana, A., \& Rochadi, D. (2019). Pengaplikasian Augmented Reality Pada Modul Pembelajaran Menggambar Teknik 2 dan CAD di Program Studi Pendidikan Teknik Bangunan FT UNJ. Jurnal Pensil : Pendidikan Teknik Sipil, 8(2), 55104.

https://doi.org/10.21009/jpensil.v8i2 .11956.

Widalisma, M., \& Lestari, N. D. (2017). Analisis Hasil Belajar Mahasiswa Menggunakan Media Cetak dengan Media Elektronik Pada Mata Kuliah Matematika Ekonomi di Universitas PGRI Palembang Merlyn. Jurnal PINUS, 3(1), 41-48. 